\title{
Model for Improving the Framework of Multicultural Pedagogy in Russia and Germany
}

\author{
Kirstin Bebell \\ Vladimir Igorevich Bogoslovskiy \\ Herzen State Pedagogical University, Russian Federation, 191186, Saint Petersburg, Moika River Emb, 48 \\ Tatiana Valeryanovna Dobudko \\ Russia, 443090, Samara, M. Gorkogo st., 65/67 \\ Tatiana Anatolyevna Zhukova \\ Russia, 443090, Samara, M. Gorkogo st., 65/67 \\ Svetlana Anatolyevna Pisareva \\ Herzen State Pedagogical University, Russian Federation, 191186, Saint Petersburg, Moika River Emb, 48
}

Doi:10.5901/mjss.2015.v6n4s1p176

\section{Abstract}

This article analyzes the need for Russia and Germany to improve their models of multicultural pedagogy as well as the need to conduct comparative research and the role of that research in the development of multicultural pedagogy. This article underlines distinct steps necessary for conducting comparative research and discusses the need to change current perceptions towards the field of multicultural pedagogy, particularly perceptions based on cultural traditions and historical characteristics of educational systems. The authors propose a model for multicultural pedagogy that can be used during teacher training, with fundamental stages of this model presented in the article.

Keywords: multicultural pedagogy, periods of multicultural pedagogy development, stages of multicultural pedagogy development, educational cluster.

\section{Introduction}

Globalization, integration and internationalization have become fundamental aspects of modern education. One of the key issues for many of today's higher education institutions is the development of an educational system that promotes multicultural pedagogy based on the best traditions of each country's respective educational system. In addition, it is important to optimize the use of comparative studies, thus increasing opportunities to discover commonalities between different educational systems, which can in turn facilitate the development of multicultural pedagogy. Currently, researchers from around the world are studying the essence of multicultural pedagogy (Bebell K. and Bogoslovskiy V.I., 2014; Göbel, K, 2010). It is worthwhile to consider the following questions: What role does multicultural pedagogy play in the modern world? How should a country's educational policies relate to multicultural education? To what extent will multicultural pedagogy affect an individual's identity in a multicultural world? To what extent will multicultural pedagogy allow for the preservation of features of national educational systems?

This article is a continuation of a series of articles about difficulties in developing of multicultural pedagogy. The previously published articles are "Multicultural Pedagogy in Germany and Russia: Problems and Prospects" (K. Bebell, V. Bogoslovsky, T. Zhukova), "Multicultural pedagogy development in modern education" (V. Aniskin, V. Bogoslovsky, S. Pisareva, T. Zhukova).

\section{Periods of Multicultural Pedagogy Development}

Researchers around the world are dedicated to studying the foundations of multicultural pedagogy and discovering ways 
to improve it (Aniskin V.N. and Bogoslovskiy V.I., 2014; Schrenk M. and Göbel, K, 2010, Hofstede, G., 2006). Until recently, multicultural pedagogy was associated with providing the same education for people from many different cultures, an example of which is incorporating of a variety of cooperative activities that are challenging for people of different nationalities (Duzhakova, M.V., 2010; Hoehmann K., 2011; Lanfranchi, A., 2008); the pedagogy oriented towards the decreasing cultural stereotypes and reducing prejudice by encouraging interaction between diverse individuals (Hoehmann K., 2011; Schwarzer, C. and Trautner, H.M., 2006); the pedagogy aimed to promote cognitive and ethical growth amongst people throughout the world regardless of their nationality or socioeconomic status and facilitate a multicultural partnership between universities (Palatkina G.V., 2007; Schwarzer, C. and Thomas A., 2006); the pedagogy which aspires to develop students' competence in multicultural contexts. Each individual should develop multiple ways of perceiving, evaluating, believing, and solving problems (Rothlauf, J. and Ringeisen, T., 2006; Bogoslovskiy V.I., 2010); the pedagogy addresses antisocial behavior found in some countries that is directed towards the integration of multicultural factors into society (Dzhurinskiy, A.N. and Alexiadou, N. 2007; Bondarenko, E.N., 2006).

This article focuses on the primary difficulties that arise when examining the development of multicultural pedagogy in Russia and Germany. Based upon analysis of works of German and Russian researchers, (Aniskin V.N. and Bogoslovskiy V.I., 2014; Schrenk M. and Göbel, K, 2010, Hofstede, G., 2006) we recommend integrating cultural, social and educational aspects of different educational systems in order to create a multicultural pedagogy within a country's educational system. This type of multicultural pedagogy is oriented towards the development of multicultural competence in individuals. We will examine four stages in the development of multicultural pedagogy in Germany and Russia.

\subsection{Stage 1}

In Stage 1, the development of multicultural pedagogy should involve the analysis of various definitions and interpretations of multicultural tolerance in order to understand differing pedagogical developments in different countries (Bondarenko, E.N. and Bosse E., 2010). It is also essential to consider how various cultural stereotypes are interpreted in different countries and what role stereotypes play in communication processes (Schrenk M., 2010; Fleischer, J. and Leutner, D., 2012) and to discuss how universities can address the development of multicultural pedagogy (Bogoslovskiy V.I., 2010; Huisman, J., 2005).

\subsection{Stage 2}

Stage 2 involves expanding ideas about multicultural pedagogy and defining multicultural pedagogy's main objectives. Education professionals should consider the following:

1. There are few, if any, benefits in simply copying and importing one country's application of multicultural pedagogy to another country (Bogoslovskiy V.I. and Zhukova T.A. 2014). The mechanisms by which different countries integrate multicultural pedagogy into their educational systems differs from country to country (Bogoslovskiy V.I., 2014; Göbel, K, 2010, Hofstede, G., 2006), and each country must select processes appropriate to the development of higher education within that particular country's educational system.

2. Each country has differing needs and interests in the sphere of education, which lead to differing understandings of citizens' rights and duties and the need to accept individuals' cultural backgrounds while also appropriately handling conflicts (Poshtareva T.V., 2005; Lanfranchi, A. and Shogenov A.A. 2008).

3. Examine the link between psychological, cultural and pedagogical phenomena and multicultural integration (Lehman, D. R. and Schaller, M., 2004).

\subsection{Stage 3}

Stage 3 underlines the importance of creating a multicultural educational environment by optimizing cooperation between multiple countries. There must be a systemic description of the processes in educational development which incorporates the rationale of the work conducted in each country. The process of developing multicultural educational environment is a long process that emphasizes the synthesis of various movements throughout a variety of educational systems. The majority of countries examine new pedagogical movements through the perspective of historical frames of reference in the study of education. Stage 3 can be depicted using two levels, beginning with an analytical focus and moving on to critical evaluation. 


\subsubsection{Analytical level}

The analytical level involves developing a concrete description of multicultural pedagogy. At this stage the following tasks must be undertaken:

$>$ Analysis of factors influencing the educational policy of a country. It is important to consider the interest in developing multicultural pedagogy and current understanding of multicultural pedagogy in each country. It is also important to bear in mind the psychological preparation amongst stakeholders in the educational system for the development of multicultural pedagogy; the number of teachers who are willing and/or able to develop the foundations of multicultural pedagogy, and other potential factors depending on the educational processes of a particular country. (Bogoslovskiy V.I. and Pisareva S.A., 2014)

$>$ Analysis of interpretations of what "multicultural pedagogy" means in each country in order to better understand differences in the development of multicultural pedagogy. Definition of differences in how multicultural pedagogy is developed in different countries. Each country has varying interests in multicultural pedagogy which lead to difficulties in the development of multicultural pedagogy as not all countries are similarly motivated towards a particular solution or development process (Bogoslovskiy V.I., 2014; Göbel, K, 2010);

$>$ Definition of basic requirements in creating an educational program of multicultural pedagogy. The educational systems of different countries are far too diverse and complex to allow for the formation of a singular conclusion that one educational system is better than another (Miethe, I., 2007; Zhukova T., 2014; Lanfranchi, A. and Wulfson B.L., 2008). Developing an internationally integrated educational system is complex due to the fact that, on one hand, there are dissimilar understandings of the primary objective in various countries and insufficient comparative research that might have developed of a common vision on this issue (Holzinger, K., Knill, C., 2005). On the other hand, multicultural education presupposes a predetermined structure and a unified approach to its development in different countries (Bogoslovskiy V.I. and Pisareva S.A., 2014; Enders, J., 2002; Ziegele, F., 2006).

\subsubsection{Critical evaluation level}

This level involves discussion and criticism of comparative research drawn from empirical studies. One must critically analyze stakeholders with knowledge of the current system and analyze the possibility of comparing the two systems. The process of developing multicultural educational philosophies is a long process that emphasizes the synthesis of various movements throughout a variety of educational systems (Pisareva S.A., 2014; Luijten-Lub A. and van der Wende, M., 2005). The majority of countries examine new pedagogical movements through the perspective of historical frames of reference in the study of pedagogy (Ringeisen, T. and Buchwald, P., 2006). Pedagogy is rarely allotted adequately substantial consideration within the framework of pursuing international integration of educational systems (Bogoslovskiy V.I. and Pisareva S.A., 2014). Because of this, it is important for educators in both Russia and Germany to examine the following aspects.

\subsubsection{General characteristics necessary in the development of multicultural pedagogy}

Table 3. General characteristics

\begin{tabular}{|c|c|}
\hline 1. Integration within universities & $\begin{array}{l}\text { Kotler and Mindak have identified four different conceptual models to depict the } \\
\text { relationship between educational systems of different countries. The authors aim to } \\
\text { understand international collaboration and integration in education by matching } \\
\text { countries' primary goals. } \\
\text { Model 1. Countries function independently when creating a system of intercultural } \\
\text { education. A country may utilize characteristics of another country's educational } \\
\text { system only insofar as it meets the target country's own needs. Countries will } \\
\text { collaborate and communicate about education with other countries only to further } \\
\text { the goals of its own national educational system. } \\
\text { Model 2. Countries play roles of equal importance in intercultural education with } \\
\text { separate educational systems. One country may rely on other countries for a few } \\
\text { functions essential to their own educational system. The educational system } \\
\text { serves its own parent country, but shares some common ground with other }\end{array}$ \\
\hline
\end{tabular}




\begin{tabular}{|c|c|}
\hline & $\begin{array}{l}\text { countries' educational systems. In this model, there is the potential for one } \\
\text { country's educational system to demonstrate greater depth or breadth in certain } \\
\text { areas than other educational systems. } \\
\text { Model 3. One country's educational system demonstrates dominance over other } \\
\text { educational systems. This dominance allows for the development of other } \\
\text { countries' educational systems. This kind of a system is defined as a "unilateral } \\
\text { relationship" with primary consideration being given to the social good in } \\
\text { accordance with the needs of the educational system. } \\
\text { Model 4. Both educational systems are oriented towards cooperation and } \\
\text { integration. These educational systems are from two countries whose views } \\
\text { regarding multicultural education are rapidly converging. Both educational systems } \\
\text { recognize the need for shared platforms and goals, and accept the importance of } \\
\text { understanding and influencing attitudes and perceptions. }\end{array}$ \\
\hline \multirow{2}{*}{\multicolumn{2}{|c|}{$\begin{array}{l}\text { 2. Creation of plans for transition of the educational system. Development of criteria to successfully break away from older } \\
\text { pedagogies and learn new pedagogies (basic approaches, methods, goals, objectives etc.) (Göbel, K. and Hesse, H.G., Aniskin } \\
\text { V.N., 2014). } \\
\text { 3. Allowance for pedagogical independence and decentralization between the two countries in the areas of curriculum (Pisareva } \\
\text { S.A., 2014). }\end{array}$}} \\
\hline & \\
\hline \multicolumn{2}{|c|}{$\begin{array}{l}\text { 4. Development of student perception from lower levels of multicultural competence to greater multicultural understanding } \\
\text { (Hoehmann K, 2011; Göbel, K., 2009). }\end{array}$} \\
\hline
\end{tabular}

\subsubsection{Characteristics necessary in individuals to support the development of multicultural pedagogy}

1. Language knowledge and assessment (Hufeisen, B. and Neuner, G., 2009; Ziegele, F., 2008; Bosse, E., 2010; Fleischer, J., Leutner, D., 2012 etc.). One of the primary difficulties encountered in the development of multicultural pedagogy is the knowledge of foreign languages. Germany's experience in language instruction, both in German and foreign languages, provides a number of beneficial strategies for Russia to consider. Table 4 shows the leading approaches and technologies that Germany uses in teaching languages.

Table 4. German approaches and technologies for language learning

\begin{tabular}{|l|l|l|}
\hline Approach & Content of the Approach & Technologies \\
\hline Cognitive approach & Individual's facility for language learning & $\begin{array}{l}\text { Technology oriented towards determining an } \\
\text { individual's facility for learning languages (in } \\
\text { development) } \\
\text { Technology oriented towards determining an } \\
\text { individual's motivational level for learning } \\
\text { languages (in development) }\end{array}$ \\
\hline Constructive approach & $\begin{array}{l}\text { Study of the role of associative thinking as related to } \\
\text { foreign language study }\end{array}$ & $\begin{array}{l}\text { Technologies supporting problem-solving-based } \\
\text { learning } \\
\text { Technologies dedicated to promoting active } \\
\text { learning }\end{array}$ \\
\hline $\begin{array}{l}\text { Perception-readiness } \\
\text { approach }\end{array}$ & $\begin{array}{l}\text { Study of the four areas that further a positive attitude } \\
\text { and readiness to learn a foreign language system or } \\
\text { structure: (consolidation and integration of linguistic } \\
\text { knowledge; linguistic structure; linguistic } \\
\text { comparisons; ability to block "gateways" to } \\
\text { emotional resistance to new language acquisition) }\end{array}$ & $\begin{array}{l}\text { Study of foreign language learning goals } \\
\text { Social approach }\end{array}$ \\
\hline
\end{tabular}

\section{Personal preferences}

Given that the implementation of multicultural pedagogy in higher education requires the consideration of an individual's mental characteristics, as well as the overall mentality of a society, it is necessary to develop new psychological mechanisms that analyze unconscious or subconscious emotional responses to multicultural situations and 
stimuli. Over the past few decades, a variety of psychological instruments have been devised in order to promote the advancement of multicultural pedagogy. (Sen A.) writes in [Rationality and Freedom] that it is essential "to recognize that peoples' behaviour cannot be described in terms of a single complete preference ordering only. It can be driven by motivation other than self-interest, such as social commitment, moral imperatives and conventional rule-following". There are two dominant theories in understanding human preferences (Sen A., 2002). In the first of these theories it is important to define a set of statements from which a preference to the new pedagogy is obtained. It reflects self-interest and can be presented by utility function. The second theory promotes the importance of discussing observed choices instead of starting from a set of statements.

Preferences play a substantial role in the process of the development of multicultural pedagogy as well as having a significant influence on further decision-making (Lanfranchi, A., 2008; Dobudko T.V., 1999). Further research should consider how an individual's preferences might allow for more precise predictions of and individual's views on multicultural pedagogy.

\section{The Role of Clusters in the Development of Multicultural Pedagogy}

The process of developing multicultural educational philosophies is a long process that emphasizes the synthesis of various movements throughout a variety of educational systems. The majority of countries examine new pedagogical movements through the perspective of historical frames of reference in the study of pedagogy. Pedagogy is rarely allotted adequately substantial consideration within the framework of pursuing international integration of educational systems. Today, comparative research is a significant contributor to educational theory and practice in many countries. From Zaltman's point of view "research (study) should value the power of complexity of the understanding process of integration and consider the great imbalance that exists between the way of our expectations and thoughts of further cooperation. This has the aim to explain what we find preferable for integration, to know how we react in one or another way; to understand the varieties of teaching views" (Zaltman S., 2004).

Because of this, it is important for educators in both Russia and Germany to examine the educational cluster. Scientists from the both countries have recently been actively discussing clusters (Sölvell, O. and Ekimova N.V., 2009; Karlsson, Ch., 2008). There have been a significant number of papers concerning the comparison of individual components of the various educational systems in order to better understand the role of clusters. (Sölvell, O., 2009) To date, many German and Russian studies have focused on clusters, emphasizing the importance of this structural unit in education. (Karlsson, Ch., 2008, Ignatova I.B., 2009). The main advantages of clusters are that they allow for: quick access to necessary information; complementary and interdependent structures; increasing motivation to implement activities; and improving the assessment of created materials in order to encourage convergence between various universities (Goedegebuure, L. and van Vught, F., 1996).

In organizing and implementing educational clusters, one should consider the preparation, orientation, classification and forecasting of the cluster: (Bobrova, S.Y., Zhukova, N.V. and Yarovova, V.V., 2007; Sölvell, O. and Ekimova N.V., 2009)

1. Preparation allows for the definition of the conceptual apparatus used in the construction of the cluster.

2. Orienting helps in the management of empirical data and highlights the methods of collection and the amount of data to be collected.

3. The classifying function helps to integrate data into principles and promotes the construction of hypotheses and theories. Classification also helps integrate the data into general principles, which thereby contribute to the abovementioned hypotheses and theories.

4. Forecasting contributes to testing hypotheses and predictions in a scientifically sound manner. This feature allows for the explanation and prediction of future events, based on general and foundational pedagogical patterns.

Table 6 below shows the areas of educational clusters presented by the authors of the paper. 
Table 6. Topics of educational clusters

\begin{tabular}{|c|c|}
\hline \multicolumn{2}{|c|}{$\begin{array}{l}\text { Topics of educational clusters } \\
\text { How to conduct scientific research Improvement of access to education for immigrants } \\
\text { Analysis of technologies related to personal development } \\
\text { Specifics of organizing interdisciplinary learning } \\
\text { Organization of multicultural education } \\
\text { Improvement to the foundations of innovative pedagogy } \\
\text { Optimization of processes dedicated to improving the quality of training in the implementation of the competence model } \\
\text { Creation of the foundation of educational programs of the } 21 \text { st century } \\
\text { Problems and perspectives related to developing a monitoring system, as concerns different spheres of education (international } \\
\text { national, regional) }\end{array}$} \\
\hline \multicolumn{2}{|l|}{$\begin{array}{l}\text { Independent analysis of a particular thematic area } \\
\text { Preparing teachers to work with educational clusters }\end{array}$} \\
\hline \multirow{2}{*}{$\begin{array}{l}\text { Topic title } \\
\text { Analysis of a teacher's capacity for external interactions } \\
\text { Analysis of a teacher's instructional skills and knowledge }\end{array}$} & \\
\hline Analysis of a teacher's capacity for external interactions & \\
\hline Analysis of a teacher's instructional skills and knowledge & \\
\hline & \\
\hline
\end{tabular}

Given the information presented above, the authors have constructed a cohesive model of multicultural pedagogy focused improving the foundations of multicultural pedagogy in Russia and Germany. The foundational stages and components are outlined below in Figure 1.

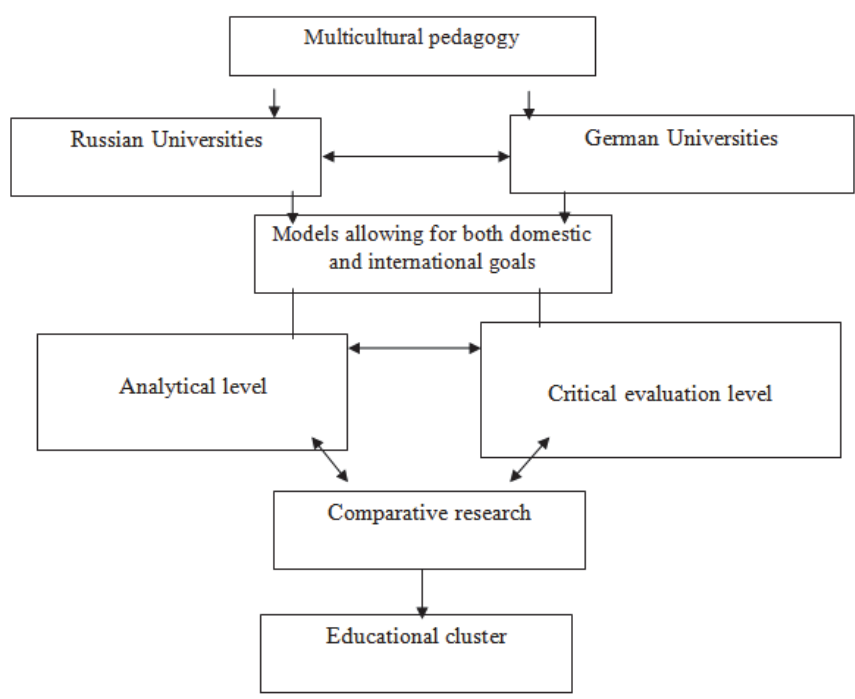

Figure 1. Model for Improving the Foundations of Multicultural Pedagogy in Russia and Germany

\section{Acknowledgements}

It is worth noting that one of the priorities of pedagogy in both Russia and Germany is the development of a model to improve the foundations of multicultural pedagogy. Through the framework of our research, we propose that the most 
significant aspect in pursuit of this goal is reorganizing the way universities in the two countries work together towards improving multicultural education. Analysis of comparative research will significantly advance this goal. The model outlined in this article consists of the significant components: analysis of the characteristics of each country's educational process; the quality and characteristics of comparative studies. In order to improve multicultural pedagogy, it is important to develop shared modules. The most significant of potential models are reflective, conceptual, linguistic and technological. A joint study conducted by Russian and German researchers has allowed us to determine the content of each module. In order to further optimize the development of multicultural pedagogy, we propose using educational clusters, which will allow for different countries to integrate their knowledge on a meaningful level.

\section{References}

Alexiadou, N. (2007). The Europeanisation of education policy: researching changing governance and 'new' modes of coordination. Research in Comparative and International Education, 2(2), 102-116.

Aniskin V.N., Bogoslovskiy V.I., Pisareva S.A., Zhukova T.A. (2014). Multicultural pedagogy development in modern education. Journal of US-China Public Administration, ISSN 1548-6591, Vol. 11, No. 6, 541-547.

Aniskin, V.N., Zhukova, T.A., Schrenk, M. (2010). The formation of students' sociocultural knowledge in Russian and German universities. Intellectual development in the process of teaching Physics, (39-41). Samara State Pedagogical University.

Bebell K., Bogoslovskiy V.I., Zhukova T.A. (2013). Multicultural pedagogy in Germany and Russia. University Scientific Journal, 6, (5059).

Bobrova, S.Y., Zhukova, N.V., Yarovova, V.V. (2007). Current questions regarding the creation of clusters as a tool for improving the competitiveness of the region. Fundamental research, 12, (508-509).

Bogoslovskiy, V.I., Zhukova, T.A. (2013). The role of multicultural pedagogics in modern education. http: gv-conference.com/actualconferences-and-papers.

Bondarenko, E.N. Teacher training in modern systems of teacher education in the world. Bulletin of Moscow University, 3, (127-136).

Bosse, E. (2010). Vielfalt erkunden - ein Konzept für interkulturelles Training an Hochschulen. In: H. Gwenn, \& S. Vogler- Lipp (Eds.), Schlüsselqualifikation interkulturelle Kompetenz an Hochschulen. Grundlagen, Konzepte, Methoden (109-133). Wiesbaden: VS Verlag für Sozialwissenschaften.

Dobudko, T. (1999). Development of professional competence within information education: a monograph, Samara.

Dzhurinskiy, A.N. (2007). Pedagogy of international communication: Multicultural education in Russia and abroad: a tutorial, 224, Moscow.

Duzhakova, M.V. (2008). Development of teacher education in a multicultural society: a monograph, Voronezh.

Ekimova N.V., Ignatova I.B. (2009). The cluster approach in the management of the educational institution. Peoples' Education, 8, (62$66)$.

Enders, J. (2002). Higher education, internationalisation, and the nation-state. German Policy Studies, 2(3), (1-33).

Fleischer, J., Leutner, D., Klieme, E. (Hrsg.). (2012). Modellierung von Kompetenzen im Bereich der Bildung. Eine psychologische Perspektive [Special issue]. Psychologische Rundschau, 63(1).

Goedegebuure, L., van Vught, F. (1996). Comparative higher education studies: The perspective from the policy sciences. Higher Education, 32, (371-394).

Göbel, K. (2010). Interkulturelle Pädagogik - die Notwendigkeit der Konkretisierung von Handlungskontexten und der Definition von Bildungszielen. Zweite Diskussionseinheit. Bonn.

Göbel, K., Hesse, H.G. (2009). Interkulturelle Kompetenz - ist sie erlernbar oder lehrbar? Konzepte für die Lehrerbildung, die allgemeine Erwachsenenbildung und die berufliche Weiterbildung. In: G. Mertens, U. Frost, W. Böhm \& V. Ladenthin (Hrsg.). Handbuch der Erziehungswissenschaftenn Band III/2. Paderborn: Schöningh Verlag, (1139-1152).

Hoehmann, K., Zhukova, T. (2011). Teaching sociocultural qualities in German and Russian universities. PGSGA, (26-30).

Hofstede, G. (2006). Lokales Denken, globales Handeln. Interkulturelle Zusammenarbeit und globales Management. Munchen: DTVBeck.

Holzinger, K., Knill, C. (2005). Causes and conditions of cross-national policy-convergence. Journal of European Public Policy, 12(5), $775-796$

Hufeisen, B., Neuner, G. (2009). Deutsch als zweite Fremdsprache. Goethe-Institut. München.

Karlsson, Ch. (2008). Handbook of research on cluster theory. Cheltenham, UK: EdwardElgar Publishing.

Kotler, P. and Mindak, W, (1978). Marketing and public relations: Should they be partners or rivals? Journal of Marketing (53-57).

Lanfranchi, A. (2008). Interkulturelle Kompetenz als Element pädagogischer Professionalität - Schlussfolgerungen für die Lehrerausbildung. Interkulturelle Kompetenz und pädagogische Professionalität. Wiesbaden, (231-260).

Lehman, D. R., Chiu, C.-Y., Schaller, M. (2004). Psychology and culture. Annual Review of Psychology 55, (689-714).

Luijten-Lub A., van der Wende, M., Huisman, J. (2005). On cooperation and competition: A comparative analysis of national policies for internationalisation of higher education in seven Western European countries. Journal of Studies in International Education, 9(2), $147-163$.

Miethe, I. (2007). Bildung und soziale Ungleichheit in der DDR. Möglichkeiten und Grenzen einer gegenprivilegierenden Bildungspolitik [Education and social inequality in the GDR. Opportunities and limits for educational policy against privileges]. Opladen: Budrich. 
Ringeisen, T., Buchwald, P., Schwarzer, C., Trautner, H.M. (2006). Interkulturalität im Ausbildungskontext. Zum Einfluss interkultureller Faktoren auf das denken, Fühlen und Handeln von Lehrkräften und Studierenden. Dokumente zur Weiterbildung und Internationalisierung an Hochschulen 4, (4-38).

Rothlauf, J. (2006). Interkulturelles Management, Oldenburg Verlag, Munchen.

Schrenk M., Zhukova T.A. (2013). On the prospects of the integration of Russian and German educational systems in information technology. Information technology in the social sphere. Samara, (62-65).

Sen, A.K. (2002). Rationality and Freedom, Cambridge MA, the Belknap Press of Harvard University Press.

Sölvell, O. (2009). Clusters: balancing evolutionary and constructive forces. Stockholm, Sweden: Ivory Tower Publishers.

Thomas A. (2006). Interkulturelle Kompetenz im Internationalen Management, in: Volkswagen Stiftung (hrsg): Wir stiften, Wissen, Tagungsband, Dresden.

Palatkina G.V. (2007). Multicultural education of young people throughout Russia. Multicultural education of youth: the principle of ethnic tolerance: monograph, Astrakhan.

Poshtareva T.V. (2005). The formation of ethnocultural competencies. Pedagogy, 3. (35-42)

Shogenov A.A. (2008). National education policy. Pedagogy, 5 (13-20).

Wulfson B.L. (2003). Comparative education: history and contemporary issues. Moscow: URAO.

Zaltman, S. (2004) Como piensan los consumidores. Madrid. Urano.

Ziegele, F. (2006). «Konzeption eines neuen Modells der staatlichen Mittelvergabe an die Hochschulen in Brandenburg Ergebnisbericht», CHE Working Paper, 51, Gütersloh. 